\title{
The Addition of Endothelial Cell Growth Factor and Heparin to Human Umbilical Vein Endothelial Cell Cultures Decreases Plasminogen Activator Inhibitor-1 Expression
}

\author{
Barbara A. Konkle* and David Ginsburg** \\ Departments of Medicine* and Human Genetics, ${ }^{\ddagger}$ University of Michigan Medical School and the Howard Hughes Medical Institute, \\ Ann Arbor, Michigan 48109
}

\begin{abstract}
Plasminogen activator inhibitor-1 (PAI-1) is a specific and rapid inhibitor of tissue plasminogen activator (tPA) and urokinase. Clinical studies suggest that PAI-1 may play a crucial role in the regulation of fibrinolysis. A number of factors modulate PAI-1 activity in endothelial cell culture, and the isolation of PAI-1 cDNA now allows study of PAI-1 regulation at the mRNA level. We examined the effect of endothelial cell growth factor (ECGF) and heparin on PAI-1 expression in human umbilical vein endothelial cell (HUVEC) culture. The addition of ECGF and heparin to HUVEC cultures results in a 3-10-fold decrease in the PAI-1 activity secreted into the conditioned media. This effect is mediated at the mRNA level. A decrease in PAI-1 is also seen with higher concentrations of ECGF alone, but is greatly enhanced by the addition of heparin. No significant change in tPA antigen or mRNA levels was observed.
\end{abstract}

\section{Introduction}

The plasminogen activators, tissue plasminogen activator (tPA) ${ }^{1}$ and urokinase (uPA), both convert plasminogen into its active form, plasmin, with subsequent degradation of polymerized fibrin. Plasminogen activators may be involved in a number of other biologic processes including ovulation, embryo implantation, neovascularization, and tissue repair (1). Additionally, tPA appears to be the primary physiologic plasminogen activator in plasma (2). Two major classes of rapidly acting specific inhibitors of tPA and uPA have been described. These are now designated plasminogen activator inhibitor-1 (PAI-1) and plasminogen activator inhibitor-2 (PAI-2) (3). PAI-1 is the major form of plasminogen activator inhibitor

This work was presented in part at the 1986 annual meeting of the American Society of Hematology (1986. Blood. 68:356a).

Address reprint requests to Dr. Konkle. Dr. Konkle's present address is Cardeza Foundation for Hematologic Research, Jefferson Medical College, 1015 Walnut Street, Philadelphia, PA 19107.

Received for publication 31 August 1987 and in revised form 21 January 1988.

1. Abbreviations used in this paper: ECGF, endothelial cell growth factor; ECGS, ECGF supplement; HUVEC, human umbilical vein endothelial cell; PAI-1, plasminogen activator inhibitor-1; PGK, phosphoglycerate kinase; RFA, reverse fibrin autography; tPA, tissue plasminogen activator; $\mathrm{uPa}$, urokinase.

J. Clin. Invest.

(C) The American Society for Clinical Investigation, Inc. 0021-9738/88/08/0579/07 \$2.00

Volume 82, August 1988, 579-585 found in the plasma of males and nonpregnant females (4). It is a $50-54-\mathrm{kD}$, acid-stable glycoprotein. An immunologically identical protein has been identified in platelets, endothelial cells, hepatoma cells, and fibrosarcoma cells (5-7). The vascular endothelial cell is thought to be the major site of syntheses for tPA, and may be a major synthetic source of plasma PAI-1 as well. PAI-1 constitutes up to $12 \%$ of released protein in bovine endothelial cell culture (1). It rapidly inhibits both tPA and UPA via the formation of a covalent enzyme-inhibitor complex which is stable to low $\mathrm{pH}$ and denaturants. PAI-1 appears to be present in both a latent and active form (8).

Clinical studies suggest that PAI-1 may play a crucial role in the regulation of fibrinolysis. Elevated PAI-1 levels have been observed in a variety of pathologic conditions associated with thrombosis $(4,9,10)$. The accelerated fibrinolysis found in patients with cirrhosis has been correlated with decreased tPA inhibition (11).

Human umbilical vein endothelial cell (HUVEC) culture has been used to study the regulation of PAI-1 synthesis in vitro. Propagation of HUVECs in culture requires an artificial support for cell matrix deposition and attachment and the addition of the bovine neuropeptide endothelial cell growth factor (ECGF) to the culture media $(12,13)$. Further supplementation of the media with heparin markedly enhances cell growth (14). Heparin has been shown to increase the affinity of ECGF for its receptor, probably through a conformational change in the ECGF peptide (15).

Several factors are known to affect PAI-1 activity and tPA antigen levels in HUVEC-conditioned media. Interleukin-1 increases PAI-1 activity (16-18), and this increase requires protein synthesis (17). tPA antigen levels are unchanged (17) or slightly decreased (18) after interleukin-1 stimulation. Thrombin increases both PAI- 1 activity $(19,20)$ and tPA antigen levels (19). Endotoxin markedly increases PAI-1 activity $(16,20,21)$, but does not affect tPA levels (20). Histamine increases tPA antigen levels but does not affect PAI-1 activity (20). Protein C decreases PAI-1 activity in such culture systems, but this effect appears to be due to the direct action of protein $\mathrm{C}$ on the PAI-1 protein (22).

With the recent isolation of PAI-1 cDNA (23-26), the regulation of PAI-1 synthesis can now be readily studied at the mRNA level. By nucleotide sequence analysis, PAI-1 cDNA encodes a protein containing 402 amino acids with a predicted, nonglycosylated molecular mass of $45 \mathrm{kD}$. There is extensive homology between PAI-1 and other members of the serine protease inhibitor supergene family. Cultured HUVECs contain two PAI-1 mRNA species both encoded by a single gene and differing only in the presence of an additional $1 \mathrm{~kb}$ in the $3^{\prime}$-untranslated region of the larger message (23).

We have examined the effect of ECGF and heparin on PAI- 1 expression in HUVEC. The addition of ECGF and hep- 
arin to HUVEC cultures results in a 3-10-fold decrease in the PAI-1 activity secreted into the conditioned media. This effect is mediated at the mRNA level. A decrease in PAI-1 is also seen with high concentrations of ECGF alone but is greatly enhanced by the addition of heparin to the culture media.

\section{Methods}

HUVEC culture. HUVECs were propagated from pooled primary cultures of human umbilical veins (gift of S. Weiss, University of Michigan) as previously described $(12,13)$. Cells were grown on gelatin (type 1 porcine skin, Sigma Chemical Co., St. Louis, MO)-coated tissue culture flasks (Corning Medical, Corning; NY) or dishes (Falcon Labware, Cockeysville, MD) in Hepes-buffered Mi99 média (Gibco, Grand Island, NY) with $10 \%$ fetal bovine serüm (Hyclone Laboratories, Logan, UT) in a $5 \% \mathrm{CO}_{2}$ humidified atmosphere at $37^{\circ} \mathrm{C}$. Media for primary cultures contained no heparin; except where indicated, and were supplemented with penicillin $(100 \mathrm{U} / \mathrm{ml})$ and streptomycin $(100 \mu \mathrm{g} / \mathrm{ml})$. In a given experiment all cells were grown in the same lots of fetal bovine serum, ECGF, and heparin. Except where noted, culture media were supplemented with $100 \mu \mathrm{g} / \mathrm{ml}$ of ECGF supplement (ECGS) or $4 \mathrm{ng} / \mathrm{ml}$ of ECGF (Collaborative Research, Inc., Bedford, $\mathrm{MA})$ and $100 \mu \mathrm{g} / \mathrm{ml}$ of porcine intestinal heparin (152 U/mg, Gibco). For studies without heparin and/or ECGF, the above media were removed from all cultures, the cells were rinsed twice with Dulbecco's phosphate-buffered saline (PBS) (Gibco) and then maintained in the test media for times of $24 \mathrm{~h}$ up to two passages, as noted. Cell cultures were fed every 2-3 d and for each experiment all cells were harvested at the same time point 24-36 h after refeeding. For studies on primary cultures, the cells ivere obtained from three to four pooled cords, seeded at $2-4 \times 10^{4}$ cells per $\mathrm{cm}^{2}$ onto a 24 -well cell culture cluster dish, and studied at confluency. All other studies were performed on confluent HUVEC cultures at the fourth or fifth passage except where indicated.

RNA isolation. Conditioned media were removed, centrifuged at $800 \mathrm{~g}$ for 5 min to remove cellular debris, acidified to pH 5 with $1 \mathrm{~N}$ $\mathrm{HCl}$, and stored at $-70^{\circ} \mathrm{C}$ for later analysis. The cells were washed twice with PBS. Total cellular RNA was isolated by immediate solubilization of the cells in guanidine hydrochloride as previously described (27). Briefly, cells were gently scraped into guanidine $\mathrm{HCl}$ using a rubber policeman. This solution was then sonicated and centrifuged to remove cellular debris, and the RNA was serially ethanol-precipitated from guanidine $\mathrm{HCl}$ followed by phenol extraction and further ethanol precipitation. The RNA was quantified by optical density at $260 \mathrm{~nm}$ and by visual estimation of ribosomal RNA content by ethidium bromide staining after electrophoresis in a denaturing formaldehyde gel (28).

RNA analysis. RNA was analyzed by both Northern blotting (28) and slot blot analysis. For the latter, RNA was denatured (in $1.7 \%$ formaldehyde; $15 \times \mathrm{SSC}$ [ $2.25 \mathrm{M} \mathrm{NaCl}, 0.225 \mathrm{M}$ sodium citrate] at $65^{\circ} \mathrm{C}$ ) and spotted onto a nylon membrane (Hybond-N, Amersham Corp., Arlington Heights, IL) through a vacuum manifold slot blot apparatus (Hybrislot, Bethesda Research Laboratories, Gaithersburg, MD). In both methods, the RNA was fixed to the nylon membrane with ultraviolet irradiation, prehybridized in $1 \mathrm{M} \mathrm{NaCl}, 0.1 \% \mathrm{SDS}$, and $10 \%$ dextran for $3 \mathrm{~h}$ at $68^{\circ} \mathrm{C}$, and hybridized at $68^{\circ} \mathrm{C}$ for $12-24 \mathrm{~h}$ in the prehybridization solution with the addition of $3 \mathrm{mg} / \mathrm{ml}$ sonicated salmon sperm DNA and the appropriate radiolabeled probe. Probes used included (a) PAI-1 cDNA, the 2-kb EcoRI insert of PAIB6 (23); (b) tPA cDNA (kindly provided by S. Degan, University of Cincinnati), the 2-kb BglII fragment (middle probe) of full-length tPA cDNA (29); (c) thrombospondin cDNA (kindly provided by V. Dixit, University of Michigan), the 1.9-kb SacI fragment from the 5 ' end of the cDNA (30); (d) 8.2-kb full-length von Willebrand factor (vWF) cDNA constructed from clones pvWH33, pvWH7, arid pvWE6 (27); and $(e)$ cDNA for the "housekeeping gene" phosphoglycerate kinase (PGK), the 1.8-kb PstI insert of pHPGK-7e (31). cDNA inserts were radiolabeled directly in low melting agarose bỳ rändom hexamer priming (32).
The blots were washed to high stringency $(0.1 \times$ SSC, $0.1 \%$ SDS, $1 \mathrm{mM}$ EDTA [pH 8], $10 \mathrm{mM}$ sodium phosphate [pH 6.8], at $68^{\circ} \mathrm{C}$ ) and analyzed by autoradiography with 1 Cronex intensifying screen (Dupont Co., Hoffman Estates, IL) at $-70^{\circ} \mathrm{C}$ over a wide range of exposure times $(2 \mathrm{~h}$ to $7 \mathrm{~d})$. Individual blots were rehybridized with a second radiolabeled probe after incubation in $5 \mathrm{mM}$ Tris $\mathrm{HCl}$ ( $\mathrm{pH} 7.5$ ), $2 \mathrm{mM}$ EDTA (pH 8), $0.1 \times$ Denhardt's at $68^{\circ} \mathrm{C}$ for $3-4 \mathrm{~h}$ to remove the original probe, with successful "stripping" confirmed by autoradiography.

Densitometric analysis. Densitometric analysis was performed using the GS300 scanning densitometer and the GS 350 data system (Hoefer Scientific Instruments, San Francisco, CA). Serial twofold dilutions of total cellular RNA from cells grown under designated conditions were analyzed by slot blotting using radiolabeled PAI-1 cDNA as probe (see above). Autoradiography was performed for multiple time periods in order to obtain exposures in the linear range of the film; the latter was determined by scanning slot blots of twofold dilutions of cold PAI-1 cDNA plasmid probed with radiolabeled PAI-1 cDNA. Slot blots exposed within the linear range were selected by visual comparison to the standard film. Densitometry results were normalized to scans of the same blot reprobed with PGK. The data were analyzed statistically using the paired Student $t$ test (33).

PAI-1 functional activity. PAI-1 functional activity was measured both by reverse fibrin autography (RFA) (34) and by use of a commercial amidolytic assay kit (Spectrozyme, American Diagnostica, Greenwich, CT). RFAs were performed after sodium dodecyl sulfate-polyacrylamide gel electrophoresis (SDS-PAGE) through a 3\% stacking, 8\% running gel. The gel was soaked in $2.5 \%$ Triton for $90 \mathrm{~min}$ and then applied to a fibrin agar film (1\% low-melting agarose, $2.4 \mathrm{mg} / \mathrm{ml} \mathrm{fi-}$ brinogen, $0.4 \mathrm{U} / \mathrm{ml}$ thrombin, $0.2 \mathrm{U} / \mathrm{ml}$ plasminogen) to which either $3 \mathrm{IU}$ of low molecular weight urokinase or 1 IU of tPA had been added. Lysis-free zones were analyzed by photographing the plate after 10-48 $h$ of incubation. The areas of lysis inhibition were traced on paper, cut out, and weighed on an anlalytical balance for quantification (34). The Spectrozyme assay measures PAI- 1 functional activity by the inactivation of a known amount of exogenously added tPA. PAI- 1 activity is expressed as units of tPA inhibited per milliliter of the assay sample.

$t P A$ antigen levels. tPA antigen levels were determined using the Imubind-5 tPA Elisa kit (Ametican Diagnostica). Levels were detèrmined in conditioned media alone, in conditioned media with L (Sigma Chemical Co.) added after harvesting $(0.5 \mathrm{M}$ final concentration), and in conditioned media to which heparin $(100 \mu \mathrm{g} / \mathrm{ml}$ final concentration) had been added after harvesting.

\section{Results}

Decrease in HUVEC-secreted PAI-1 activity with the addition of heparin. Varying concentrations of heparin were added to HUVEC cultures in the presence of $100 \mu \mathrm{g} / \mathrm{ml} \mathrm{ECGS.} \mathrm{PAI-1}$ functional activity in the conditioned media was measured using both the Spectrozyme assay and RFA. Using the Spectrozyme assay, a progressive decrease in PAI-1 functional activity in the conditioned media was observed with increasing heparin concentration as shown in Fig. 1. Assays were performed on media from cells grown in the presence of the test concentration of heparin for two passages and harvested at confluency at the fifth passage. The results Shown are the mean values \pm 2 SD from three independent experiments. The difference between the PAI-1 functionfal activity in conditioned media from cells grown in the absence of heparin for two passages $(6.27 \pm 0.11 \mathrm{IU} / \mathrm{ml})$ vs. PAI-1 functional activity in media from cells grown in the presence of $100 \mu \mathrm{g} / \mathrm{ml}$ heparin (1.23 \pm 0.6$)$ was significant with a $P$ vảlue $<0.01$ (paired $t$ test). Unconditioned media contained no significant PAI-1 activity by this assay. Samples were also studied by RFA as shown in Fig. $2 A$. With incubation spontaneous lysis and clearing of the fibrin film occurred, except in areas of PAI-1 activity which 


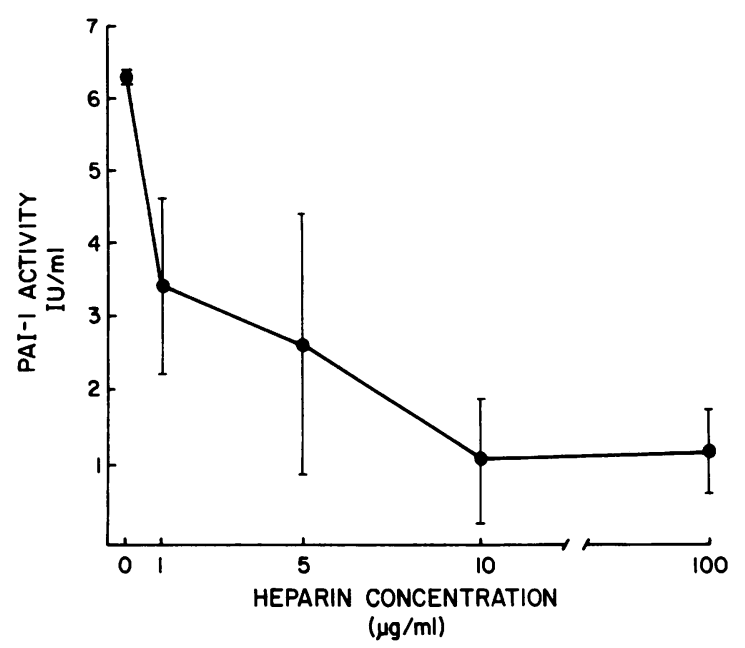

Figure 1. PAI-1 activity in conditioned media from HUVEC grown in varying concentrations of heparin. Conditioned media were harvested $30 \mathrm{~h}$ after refeeding from fifth-passage confluent HUVEC grown for two passages in $100 \mu \mathrm{g} / \mathrm{ml} \mathrm{ECGS}$ and varying concentrations of heparin from 0 to $100 \mu \mathrm{g} / \mathrm{ml}$. The media were centrifuged at $800 \mathrm{~g}$ for $5 \mathrm{~min}$ to remove cellular debris, acidified to $\mathrm{pH} 5$ with $1 \mathrm{~N}$ $\mathrm{HCl}$, and stored at $-70^{\circ} \mathrm{C}$. PAI- 1 activity was determined using the Spectrozyme assay and results are expressed as IU/ml of tPA inhibited. Values shown are the mean \pm 2 SD of three independent experiments.

appear as opaque, lysis-resistant zones. There is a progressive decrease in the size of the protected zone with increasing heparin concentrations. Minimal inhibition is seen from $100 \%$ FBS and no PAI-1 activity is detected by this assay in control unconditioned media with or without added heparin to 100 $\mu \mathrm{g} / \mathrm{ml}$.

Secreted PAI-1 activity in primary HUVEC cultures. To determine whether this observed decrease in PAI-1 activity in the presence of heparin and its dependence on ECGF (see below) are dependent on HUVEC passage in culture, conditioned media from primary HUVEC cultures were studied. A similar effect on PAI-1 was observed in conditioned media from primary HUVEC cultures. Cells were maintained for $3 \mathrm{~d}$ in media containing both heparin and ECGS, heparin without ECGS, ECGS without heparin, or neither heparin nor ECGS. The media were evaluated by RFA as shown in Fig. $2 \mathrm{~B}$. Media from cells grown in both heparin and ECGS produce the smallest lysis-resistant zone and media from cells grown in neither ECGS nor heparin produce the largest lysis-resistant zone, similar to the results seen with fifth passage HUVEC (Fig. $2 \mathrm{~A}$ ). Intermediate values were seen with heparin alone or ECGF alone. These results were confirmed in four independent experiments from two separate pooled primaries. In one experiment the results were also confirmed using the Spectrozyme assay. Because of limitations of cell number, additional studies at the mRNA level were performed on passaged HUVEC.

Studies of HUVEC PAI-1 $m R N A$. Northern blot analysis of total cellular RNA prepared from cells maintained in media containing ECGS $(100 \mu \mathrm{g} / \mathrm{ml})$ either with or without supplemental heparin $(100 \mu \mathrm{g} / \mathrm{ml})$ is shown in Fig. $3 A$. A marked decrease in PAI-1 mRNA is seen with the addition of heparin to the culture media. Both the 3- and 2-kb PAI-1 mRNA species are affected. The equal signal intensities seen upon

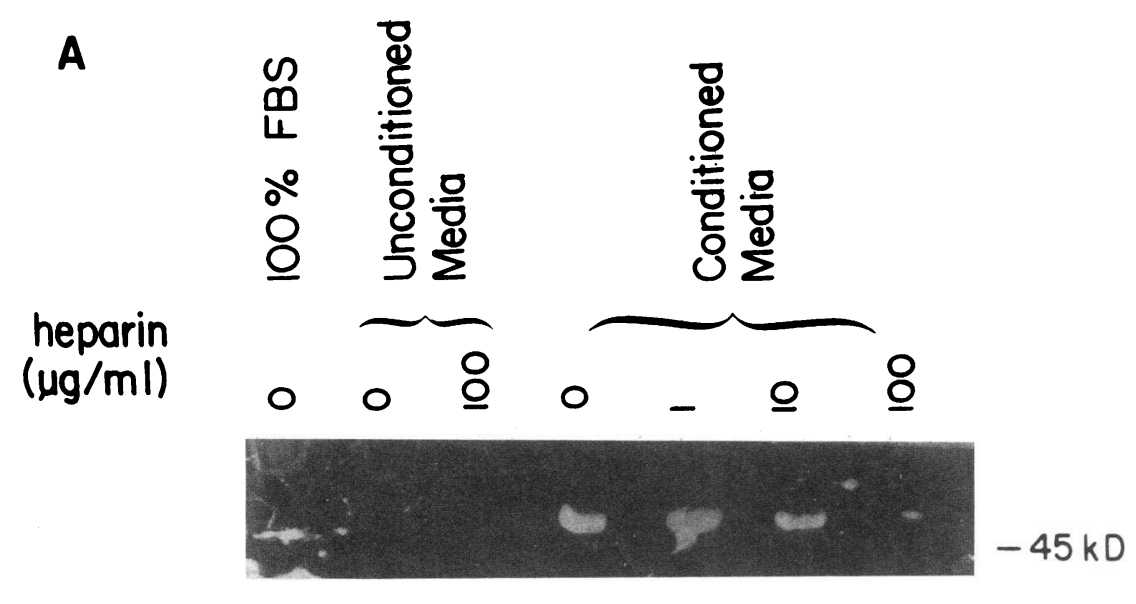

B
Figure 2. (A) Analysis of PAI-1 activity in HUVEC conditioned media by RFA. Conditioned media were removed $30 \mathrm{~h}$ after refeeding from fifth-passage confluent HUVEC grown for two passages in 100 $\mu \mathrm{g} / \mathrm{ml}$ ECGS and varying concentrations of heparin from 0 to $100 \mu \mathrm{g} / \mathrm{ml} .10-\mu \mathrm{l}$ aliquots of these conditioned media, "unconditioned" media, or FBS were subjected to SDS-PAGE. The portion of the gel including proteins of mol wt 29,000-66,000 was excised and analyzed by RFA. With incubation, spontaneous lysis and clearing of the fibrin film occurred except in areas of PAI-1 activity which appear as opaque lysis-resistant zones. Molecular weight standards used: phosphorylase B, 97,400; bovine albumin, 66,000; egg albumin, 45,000; and carbonic anhydrase, 29,000 (Sigma Chemical Co.). (B) RFA of conditioned media from primary HUVEC culture grown with or without heparin and/or ECGS. Cultures were maintained in the test media as indicated for $3 \mathrm{~d}$ beginning $4 \mathrm{~d}$ after harvesting. Samples were adjusted for cell count and subjected to SDS-PAGE. The portion of the gel including proteins of mol wt 29,000-66,000 was excised and analyzed by RFA. 


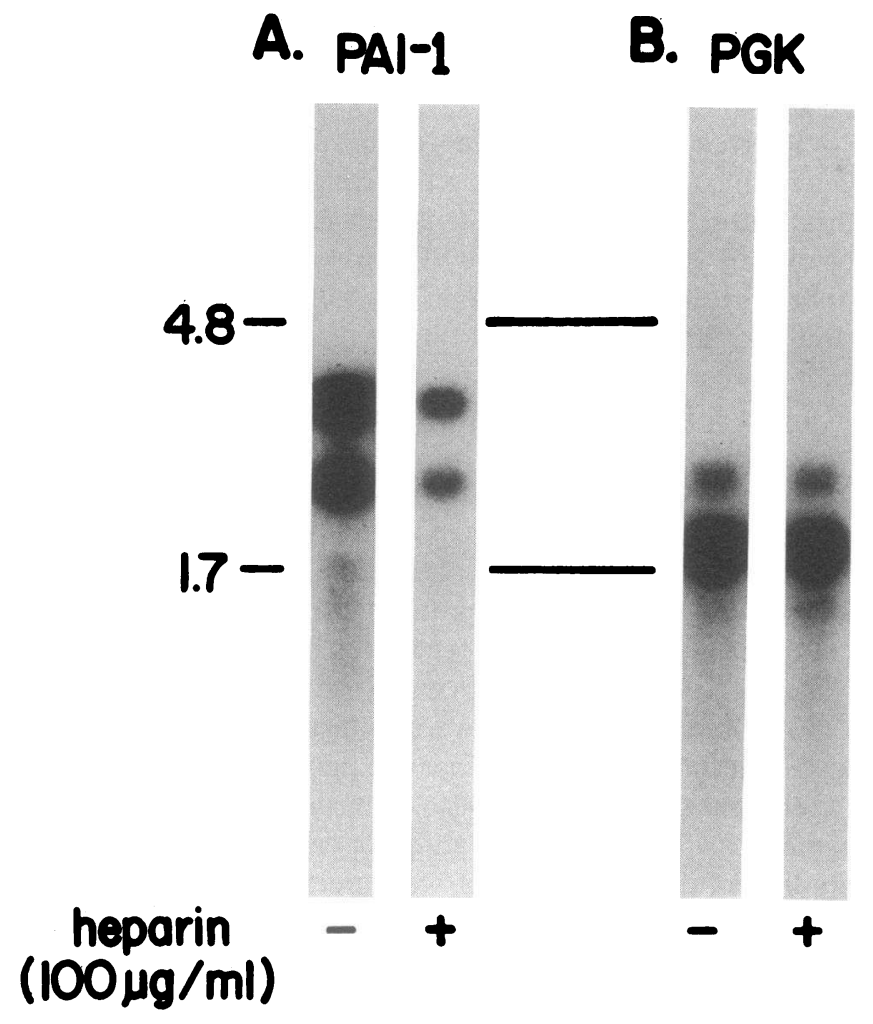

Figure 3. Decrease in HUVEC PAI-1 mRNA with the addition of heparin. Northern blot analysis was performed on $10 \mu \mathrm{g}$ of total cellular RNA from confluent HUVEC cultures maintained with $(+)$ or without $(-)$ supplemental heparin $(100 \mu \mathrm{g} / \mathrm{ml})$ for $24 \mathrm{~h}$. ECGS $(100$ $\mu \mathrm{g} / \mathrm{ml}$ ) was present in both cultures. The blot was probed with PAI-1 cDNA $(A)$ and after removal of the PAI-1 probe, reprobed with PGK cDNA $(B)$ as control for total cellular mRNA quantity. The relative positions of ribosomal RNA size markers (in kilobases) are indicated.

rehybridization with the "housekeeping" gene PGK, indicate the presence of equivalent amounts of cellular mRNA in each lane (Fig. $3 \mathrm{~B}$ ). Similar results were obtained in six independent experiments.

In order to more precisely quantify this decrease in PAI-1 mRNA, serial twofold dilutions of $4 \mu \mathrm{g}$ of total cellular RNA from HUVEC cultures grown either with or without supplemental heparin were applied to nylon filters in a slot blot apparatus. Slot blot filters were probed with PAI-1 cDNA, then "stripped," and rehybridized with PGK cDNA, as control. Analysis of pooled densitometric data from three independent experiments reveals a $4.4 \pm 1.4$-fold decrease in PAI-1 mRNA in the presence of heparin (mean $\pm 2 \mathrm{SD}$ ).

Fig. $4 \mathrm{~A}$ shows Northern blot analysis of total RNA prepared from HUVEC grown in media supplemented with heparin over a range of concentrations for two passages. A maximal decrease in PAI-1 mRNA is already evident at $10 \mu \mathrm{g} / \mathrm{ml}$ of heparin. The same blot reprobed with PGK as control (Fig. 4 $B$ ) reflects minor variation in the quantity of mRNA loaded in each lane which may account for some of the differences in PAI-1 mRNA signal intensities. A maximal effect on PAI-1 mRNA observed at heparin concentrations of 10,50 , and 100 $\mu \mathrm{g} / \mathrm{ml}$ was confirmed by quantitative slot blot analysis.

$24 \mathrm{~h}$ after a change to fresh media without heparin, PAI-1 mRNA had returned to levels similar to those observed in cells grown without supplemental heparin for two passages. A simi-

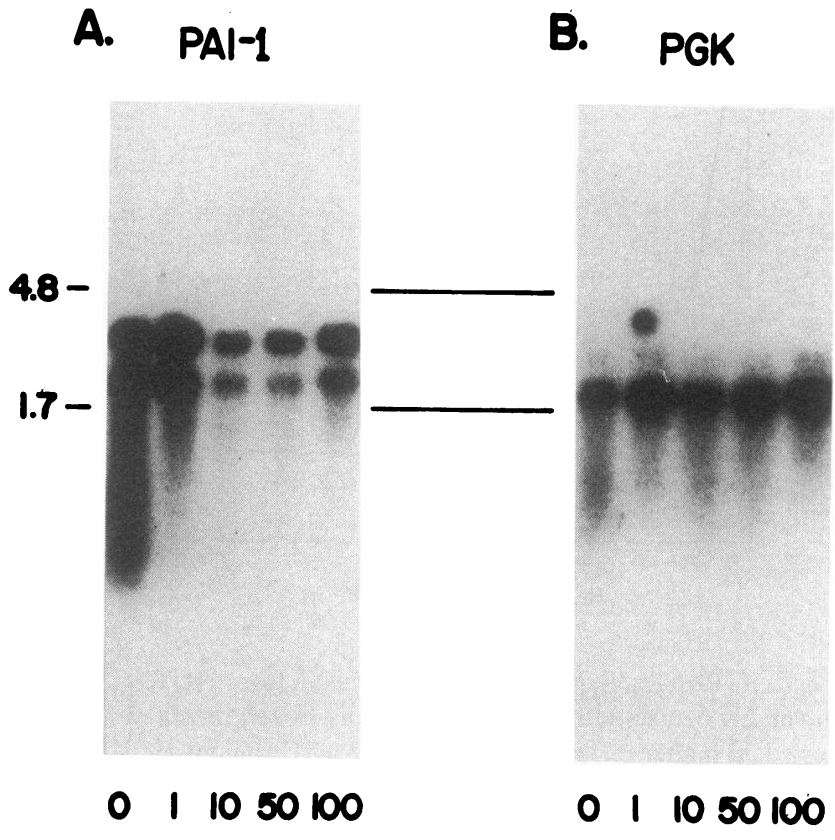

\section{HEPARIN CONCENTRATION $(\mu \mathrm{g} / \mathrm{ml})$}

Figure 4. Northern blot analysis of total RNA prepared from HUVEC grown in media supplemented with heparin over a range of concentrations. $5 \mu \mathrm{g}$ of total cellular RNA from HUVEC grown with or without heparin for 2 passages was analyzed. Heparin concentrations were as indicated. The blot was probed with PAI-1 CDNA (A) and reprobed with PGK CDNA as control (B).

lar decrease in HUVEC PAI-1 mRNA with the addition of heparin was also seen in RNA from cells harvested during log-phase growth, although the difference was less marked than that observed in confluent cells. Northern blot and slot blot analyses of RNA from cells grown with or without supplemental heparin in the culture media were also probed with cDNAs for the endothelial specific protein, von Willebrand factor, and the matrix protein, thrombospondin. No significant changes in the levels of mRNA for these proteins were observed (data not shown).

ECGF requirement for the decrease in PAI-1 $m R N A$. Fig. 5 shows analysis of cells maintained in media containing varying concentrations of heparin and ECGS. In the absence of supplemental ECGS, the addition of heparin $(100 \mu \mathrm{g} / \mathrm{ml})$ to the culture media produced no decrease in PAI-1 mRNA (lanes 1 and 2), and at these concentrations, both agents were required for the effect (lane 3). In a separate experiment (lanes 4-6), supplementation of HUVEC culture media with high concentrations of ECGS $(500 \mu \mathrm{g} / \mathrm{ml})$ (lane 5) in the absence of heparin did show an effect on PAI-1 mRNA, intermediate between the level seen with both heparin $(100 \mu \mathrm{g} / \mathrm{ml})$ and ECGS $(100$ $\mu \mathrm{g} / \mathrm{ml}$ ) (lane 6) or ECGS $(100 \mu \mathrm{g} / \mathrm{ml}$ ) alone (lane 4). A heparin concentration of $200 \mu \mathrm{g} / \mathrm{ml}$ in the absence of ECGS produced no decrease in PAI-1 mRNA (data not shown). In a separate experiment, HUVECs were maintained in media with $4 \mathrm{ng} / \mathrm{ml}$ of purified ECGF with or without supplemental heparin. As shown in Fig. 6, the same results are seen with purified ECGF with or without heparin (lanes 3 and 4) with the more crude ECGS preparation with or without heparin (lanes 1 and 2). 


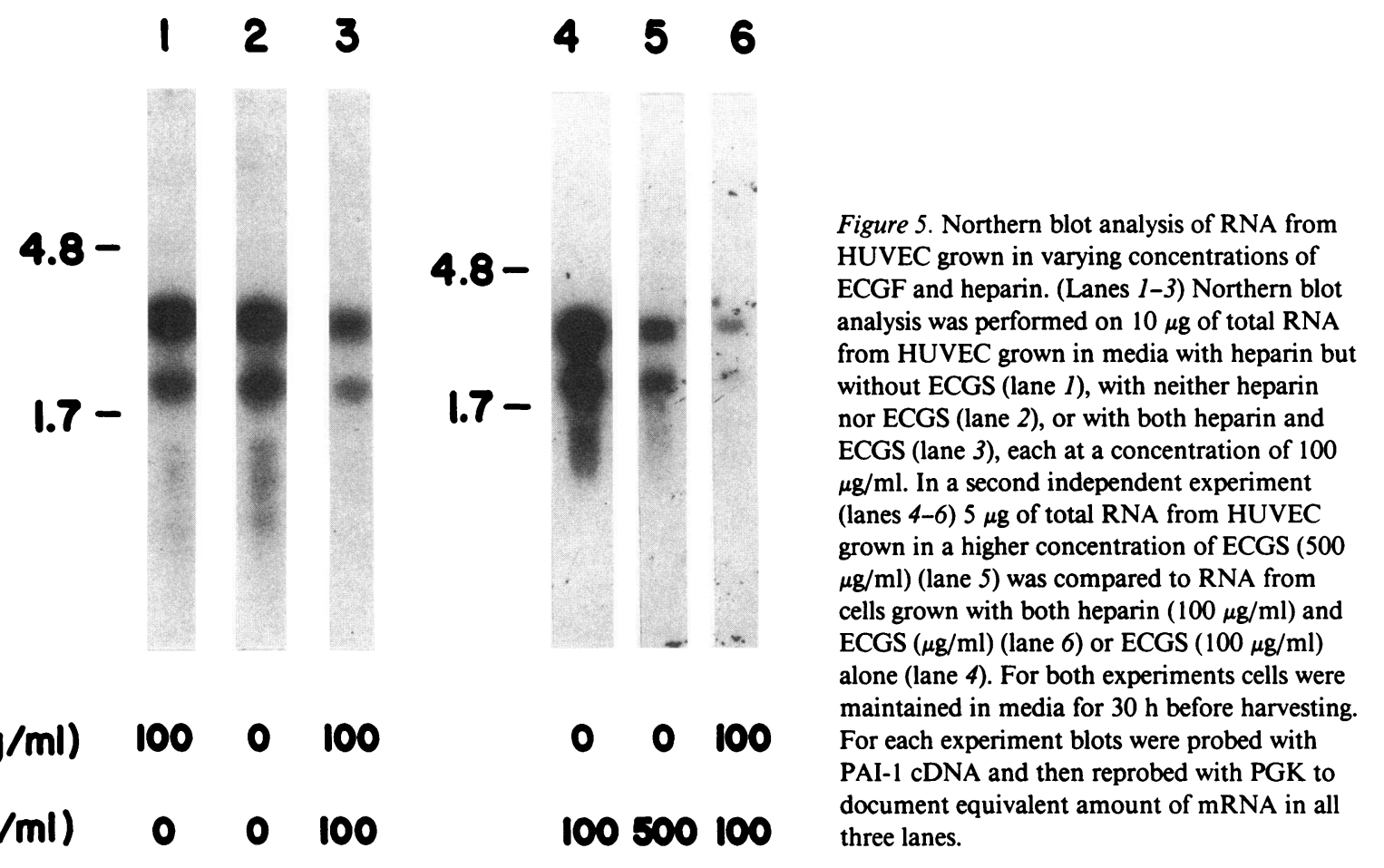

Thus the observed changes in PAI-1 mRNA with the addition of heparin appear to be due to an interaction with ECGF and not a contaminant in the ECGS preparation.

Effect of ECGF/heparin on IPA expression in HUVEC. TPA antigen levels were measured in conditioned media from HUVEC grown with or without supplemental heparin for two passages. tPA antigen levels were reproducibly higher in conditioned media from cells grown with supplemental heparin (+ media) than in media from cells without heparin supplementation (- media). However, these differences are probably due to increased tPA detection in the presence of heparin. Wun and Capuano (35) have shown that a number of compounds, including heparin, increase IPA antigen detection in normal pooled plasma, with the greatest effect seen with L-lysine and heparin. Addition of heparin $(100 \mu \mathrm{g} / \mathrm{ml}$ final concentration) to "- media" abolished the difference in tPA antigen levels between the latter and "+ media." A similar effect was seen with the addition of L-lysine $(0.5 \mathrm{M}$ final concentration) to both samples.
The effect of heparin/ECGS on HUVEC tPA mRNA was also evaluated. Northern blot analysis of $5 \mu \mathrm{g}$ total cellular RNA from cells cultured in media containing ECGS with or without supplemental heparin and probed with radioactive cDNA for tPA is shown in Fig. 6 (lanes 5 and 6 ). No significant difference in the tPA mRNA level was seen.

\section{Discussion}

PAI-1 may serve as a major control point in the regulation of fibrinolysis via its rapid interaction with tPA. Both thrombotic and hemorrhagic disorders in humans have been associated with alterations in PAI-1 and/or tPA activity $(4,9-11)$. The vascular endothelium may represent the major site of synthesis for plasma PAI-1 (1). A number of factors have been reported to affect PAI-1 activity in endothelial cell culture, although these have not generally been studied at the mRNA level. We have shown that ECGF/heparin decreases HUVEC PAI-1 activity in both passaged and primary HUVEC cell culture and that this effect is mediated at the mRNA level.

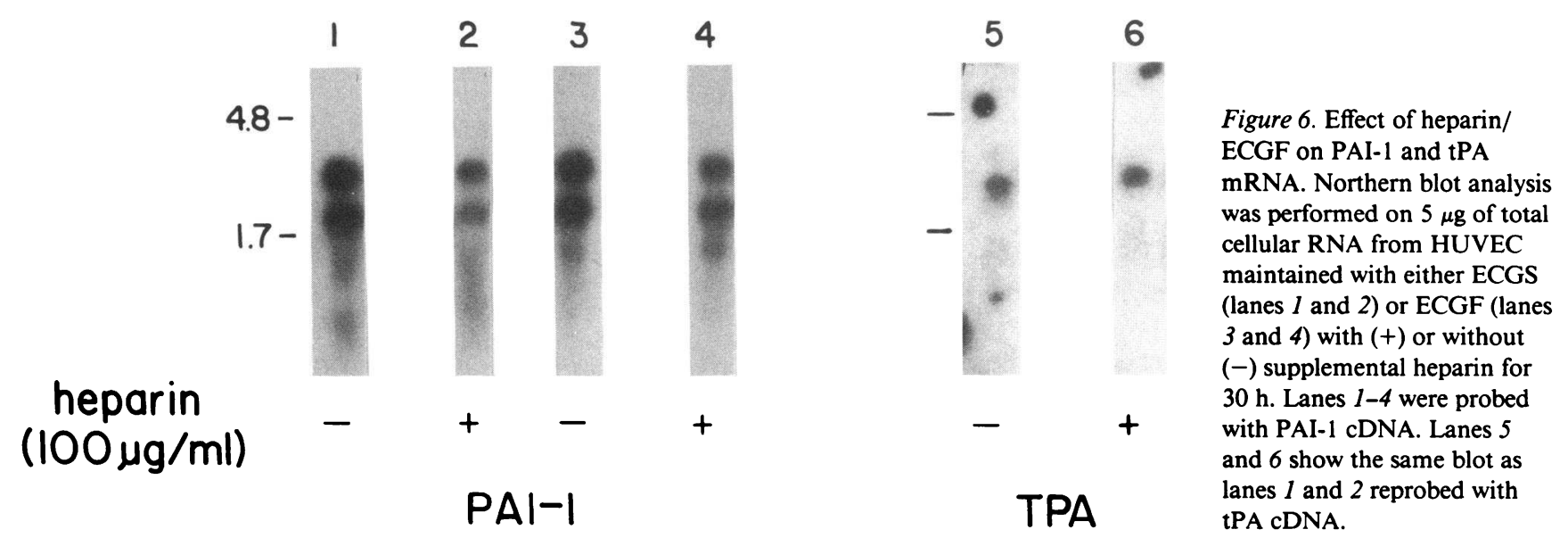


Net fibrinolytic activity reflects a balance between tPA and PAI-1. Changes in one level could be offset or accentuated by changes in the other. ECGF/heparin supplementation of HUVEC culture media does not significantly affect tPA antigen or mRNA levels and thus the observed decrease in PAI-1 should produce a net increase in fibrinolytic activity. The ECGF/heparin mediated decrease in HUVEC PAI-1 activity and mRNA levels was observed with heparin concentrations as low as $1 \mu \mathrm{g} / \mathrm{ml}(0.15 \mathrm{U} / \mathrm{ml})$ and was near maximal at concentrations of $5-10 \mu \mathrm{g} / \mathrm{ml}(0.6-1.5 \mathrm{U} / \mathrm{ml})$. These concentrations are within the range of plasma levels obtained in vivo when heparin is used pharmacologically as an antithrombotic agent (36). In a rabbit model of thrombosis, clot propogation was prevented at heparin concentrations of $0.3-0.5$ $\mathrm{U} / \mathrm{ml}$ (37).

This observed decrease in PAI-1 mRNA appears to be mediated via ECGF and is enhanced in a dose-dependent fashion by the addition of heparin. The mitogenic effect of heparin on HUVEC also appears to be dependent on its interaction with ECGF and is not seen with increased concentrations of heparin alone (up to $900 \mu \mathrm{g} / \mathrm{ml}$ ) (14). A similar interaction has been observed in fetal rat calvariae where ECGF stimulates DNA synthesis (38). Heparin has been shown to increase the affinity of ECGF for its receptor, probably through a conformational change in the ECGF peptide (15). Without supplemental heparin, some decrease in PAI-1 mRNA was still observed in cells grown in the presence of high ECGF concentrations ( 500 $\mu \mathrm{g} / \mathrm{ml}$ ECGS). These observations are consistent with heparin's effect on PAI-1 mRNA being mediated via its interaction with ECGF. Many other polypeptide growth factors bind heparin; however, physiologic mechanisms resulting from this interaction have not been well characterized (39). Heparin is an anionic, sulfated, glycosoaminoglycan similar to those found on the endothelial cell surface in vivo and in vitro (40). A glycosoaminoglycan-growth factor interaction at the endothelial cell surface might play an important role in the regulation of fibrinolysis.

Bovine endothelial PAI-1 mRNA expression is known to vary with different serum preparations used in the culture media (41). In our studies the same lot of bovine serum was used for a given experiment and media were changed in test and control cultures at the same time points. The mechanism(s) responsible for this serum mediated changes in PAI-1 mRNA levels is unknown, but could include variations in the concentration of endothelial cell growth factor and/or heparin or related compounds.

We have shown the ECGF/heparin mediated decrease in PAI-1 using both a crude preparation of ECGF from bovine hypothalamus (ECGS) and the purified ECGF (Fig. 6). Although the data in Fig. 6 were not precisely quantitated, the decrease in PAI-1 mRNA level is less marked when the media were supplemented with the more purified factor. Of note, heparin is used in the purification of this factor and a small amount of heparin ( $\sim \mu \mathrm{g} / \mu \mathrm{g}$ ECGF) is present in the final preparation (Collaborative Research). Although we cannot say whether the heparin used in processing this preparation affected our results, its presence should be considered in the evaluation of experimental data obtained using this product.

The observed decrease in PAI-1 mRNA levels in the presence of ECGF/heparin could result from a change in either the rate of PAI-1 mRNA synthesis or degradation, that is, either via a transcriptional or posttranscriptional mechanism. A number of other growth factor mediated events have been shown to be regulated, at least in part, at the level of transcription (39). PAI-1 mRNA contains an unusual 75-bp "AU"-rich sequence in its $3^{\prime}$ untranslated region (23). Similar sequences have been noted in the 3 -untranslated regions of the mRNAs for a number of proteins termed "inflammatory mediators" (42). The 3' "AU"-rich sequence from the cDNA for one of these proteins, granulocyte-macrophage colony-stimulating factor, has been shown to markedly decrease mRNA stability in NIH3T3 cells when inserted into the $3^{\prime}$-untranslated region of a recombinant $\beta$-globin expression construct (43). Unlike many of these "inflammatory mediators," PAI-1 mRNA is very stable $\left(t_{1}>8 \mathrm{~h}\right.$, Konkle and Ginsburg, unpublished data) and changes in $t_{\frac{1}{2}}$ which could result in major differences in steady state mRNA levels may be more difficult to detect.

In summary, we have demonstrated a 3-10-fold decrease in PAI-1 activity and mRNA levels in HUVEC with the addition of heparin and ECGF to the culture media. This effect appears to be mediated via ECGF and is enhanced by the addition of heparin. No significant change is seen in tPA mRNA or protein levels under the same conditions. Heparin's primary mode of action as a clinical anticoagulant is thought to occur via activation of antithrombin III with subsequent inhibition of thrombin and factor Xa. An additional profibrinolytic action of heparin resulting in more rapid clot dissolution has long been suspected on clinical grounds, and is supported by in vitro studies (44-46), though the mechanism for this effect has been unknown. If the ECGF/heparin-mediated decrease in PAI-1 mRNA also occurs in vivo, this could add significantly to heparin's clinical effect by increasing tPA activity with a subsequent increase in fibrinolysis.

\section{Acknowledgments}

We thank S. Weiss and T. Gelehrter for thoughtful review and Anne Brancheau for help in preparing the manuscript.

Dr. Ginsburg is a Howard Hughes Medical Institute (HHMI) Investigator and Dr. Konkle is a HHMI Research Associate. This work was supported in part by a grant from the National Institutes of Health (HL-39137-01).

\section{References}

1. Erickson, L. A., R. R. Schleef, T. Ny, and D. J. Loskutoff. 1985. The fibrinolytic system of the vascular wall. Clin. Haematol. 14:513530.

2. Wun, T., and A. Capuano. 1987. Initiation and regulation of fibrinolysis in human plasma at the plasminogen activator level. Blood. 69:1354-1362.

3. Report of the Meeting of the Subcommittee on Fibrinolysis, Jerusalem, Israel, June 2, 1986. Thromb. Haemostasis. 56:415-416.

4. Sprengers, E. D., and C. Kluft. 1987. Plasminogen activator inhibitors. Blood. 69:381-387.

5. Erickson, L., C. M. Hekman, and D. J. Loskutoff. 1985. The primary plasminogen-activator inhibitors in endothelial cells, platelets, serum, and plasma are immunologically related. Proc. Natl. Acad. Sci. USA. 82:8710-8714.

6. Sprengers E. D., H. M. G. Princen, T. Kooistra, and V. W. M. Van Hinsbergh. 1985. Inhibition of plasminogen activators by conditioned medium of human hepatocytes and hepatoma cell line Hep G2. J. Lab. Clin. Med. 105:751-758.

7. Gelehrter, T. D., P. A. Barouski-Miller, P. L. Coleman, and B. J. Cwikel. 1983. Hormonal regulation of plasminogen activator in rat hepatoma cells. Mol. Cell. Biochem. 53/54:11-21.

8. Erickson, L. A., C. M. Hekman, and D. J. Loskutoff. 1986. 
Denaturant-induced stimulation of the beta-migrating plasminogen activator inhibitor in endothelial cells and serum. Blood. 68:12981305.

9. Juhan-Vague, I., J. Valadier, M. C. Alessi, M. F. Aillaud, J. Ansaldi, C. Philip-Joet, P. Holvoet, A. Serradimigni, and D. Collen. 1987. Deficient tPA release and elevated PA inhibitor levels in patients with spontaneous or recurrent deep venous thrombosis. Thromb. Haemostasis. 57:67-72.

10. Gore, M., S. Eldon, K. F. Trofatter, S. J. Soong, and S. V. Pizzo. 1987. Pregnancy-induced changes in the fibrinolytic balance: evidence for defective release of tissue plasminogen activator and increased levels of the fast-acting tissue plasminogen activator inhibitor. Am. J. Obstet. Gynecol. 156:674-680.

11. Hersch, S. L., T. Kunelis, and R. B. Francis, Jr. 1987. The pathogenesis of accelerated fibrinolysis in liver cirrhosis: a critical role for tissue plasminogen activator inhibitor. Blood. 69:1315-1319.

12. Gimbrone, M. A. 1976. Culture of vascular endothelium. In Prog. Hemostasis Thromb. 3:1-28.

13. Maciag, T., G. A. Hoover, M. B. Stemerman, and R. Weinstein. 1981. Serial propagation of human endothelial cells in vitro. J. Cell Biol. 91:420-426.

14. Thornton, S. C., S. N. Mueller, and E. M. Levine. 1983. Human endothelial cells: use of heparin in cloning and long-term serial cultivation. Science (Wash. DC.). 222:623-625.

15. Schreiber, A. B., J. Kenney, W. J. Kowalski, R. Friesel, T. Mehlman, and T. Maciag. 1985. Interaction of endothelial cell growth factor with heparin: characterization by receptor and antibody recognition. Proc. Natl. Acad. Sci. USA. 82:6138-6142.

16. Emeis, J. J., and T. Kooistra. 1986. Interleukin 1 and lipopolysaccharide induce an inhibitor of tissue-type plasminogen activator in vivo and in cultured endothelial cells. J. Exp. Med. 163:1260-1266.

17. Nachman, R. L., K. A. Hajjar, R. L. Silverstein, and C. A. Dinarello. 1986. Interleukin I induces endothelial cell synthesis of plasminogen activator inhibitor. J. Exp. Med. 163:1595-1600.

18. Bevilacqua, M. P., R. R. Schleef, M. A. Gimbrone, and D. J. Loskutoff. 1986. Regulation of the fibrinolytic system of cultured human vascular endothelium by interleukin I. J. Clin. Invest. 78:587591.

19. Gelehrter, T. D., and R. Sznycer-Laszuk. 1986. Thrombin induction of plasminogen activator inhibitor in cultured human endothelial cells. J. Clin. Invest. 77:165-169.

20. Hanss, M., and D. Collen. 1987. Secretion of tissue-type plasminogen activator and plasminogen activator inhibitor by cultured human endothelial cells: modulation by thrombin, endotoxin and histamine. J. Lab. Clin. Med. 109:97-104.

21. Colucci, M., J. A. Paramo, and D. Collen. 1985. Generation in plasma of a fast-acting inhibitor of plasminogen activator in response to endotoxin stimulation. J. Clin. Invest. 75:818-824.

22. Sakata, Y., D. J. Loskutoff, C. L. Gladson, C. M. Hekman, and J. H. Griffin. 1986. Mechanism of protein C-dependent clot lysis: role of plasminogen activator inhibitor. Blood. 68:1218-1223.

23. Ginsburg, D., R. Zeheb, A. Yang, U. M. Rafferty, P. A. Andreasen, L. Nielsen, K. Dano, R. V. Lebo, and T. D. Gelehrter. 1986. cDNA cloning of human plasminogen activator inhibitor from endothelial cells. J. Clin. Invest. 78:1673-1680.

24. Ny, T., M. Sawdey, D. Lawrence, J. L. Millan, and D. J. Loskutoff. 1986. Cloning and sequence of a cDNA coding for the human beta-migrating endothelial-cell-type plasminogen activator inhibitor. Proc. Natl. Acad. Sci. USA. 83:6776-6780.

25. Pannekoek, H., H. Veerman, H. Lambers, P. Diergaarde, C. L. Verweij, A.-J. van Zonneveld, and J. A. van Mourik. 1986. Endothelial plasminogen activator inhibitor (PAI): a new member of the SERPIN gene family. EMBO (Eur. Mol. Biol. Organ.) J. 5:2539-2544.

26. Andreasen, P. A., A. Riccio, K. G. Welinder, R. Douglas, R. Sartorio, L. S. Nielson, C. Oppenheimer, F. Blasi, and K. Dano. 1986. Plasminogen activator inhibitor type-1: reactive center and amino-ter- minal heterogeneity determined by protein and cDNA sequencing. FEBS (Fed. Eur. Biochem. Soc.) Lett. 209:213-218.

27. Ginsburg, D., R. Handin, D. Bonthron, T. Donlon, G. Bruns, S. Latt, and S. Orkin. 1985. Human von Willebrand Factor (vWF): isolation of complementary DNA (cDNA) clones and chromosomal localization. Science (Wash. DC). 228:1401-1406.

28. Maniatis, T., E. F. Fritsch, and J. Sambrook. 1982. Molecular Cloning: A Laboratory Manual. Cold Spring Harbor Laboratory, Cold Spring Harbor, NY.

29. Degan, S. J., B. Rajput, and E. Reich. 1986. The human tissue plasminogen activator gene. J. Biol. Chem. 261:6972-6985.

30. Dixit, V. M., S. W. Hennessy, G. A. Grant, P. Rotwein, and W. A. Frazier. 1986. Characterization of a cDNA encoding for the heparin and collagen binding domains of human thrombospondin. Proc. Natl. Acad. Sci. USA. 83:5449-5453.

31. Michelson, A. M., A. F. Markham, and S. H. Orkin. 1983. Isolation and DNA sequence of a full-length $\mathrm{cDNA}$ clone for human $\mathrm{X}$ chromosome-encoded phosphoglycerate kinase. Proc. Natl. Acad. Sci. USA. 80:472-476.

32. Feinberg, A. P., and B. Vogelstein. 1983. A technique for radiolabeling DNA restriction endonuclease fragments to high specific activity. Anal. Biochem. 132:6-13.

33. Colton, T. 1974. Statistics in Medicine. Little, Brown and Co., Boston.

34. Erickson, L. A., D. A. Lawrence, and D. J. Loskutoff. 1984. Reverse fibrin autography: a method to detect and partially characterize protease inhibitors after sodium dodecyl sulfate polyacrylamide gel electrophoresis. Anal. Biochem. 137:454-463.

35. Wun, T., and A. Capuano. 1987. Immunoradiometric quantitation of tissue plasminogen activator-related antigen in human plasma: crypticity phenomenon and relationship to plasma fibrinolysis. Blood. 69:1348-1353.

36. Larsen, M. L., U. Abildgaard, A. N. Teien, and K. Gjesdal. 1978. Assay of plasma heparin using thrombin and the chromogenic substrate H-D-Phe-Pip-Arg-pNA (A-2238). Thromb. Res. 13:285-288.

37. Chiu, H. M., J. Hirsh, W. L. Jung, E. Regoeczi, and M. Gent. 1977. Relationship between the anticoagulant and antithrombotic effects of heparin in experimental venous thrombosis. Blood. 49:171184.

38. Canalis, E., J. Lorenzo, W. H. Burgess, and T. Maciag. 1987. Effects of endothelial cell growth factor on bone remodeling in vitro. $J$. Clin. Invest. 79:52-58.

39. James, R., and R. A. Bradshaw. 1984. Polypeptide growth factors. Annu. Rev. Biochem. 53:259-292.

40. Rosenberg, R. 1985. Role of heparin and heparin-like molecules in thrombosis and atherosclerosis. Fed. Proc. 44:404-409.

41. Sawdey, M., T. Ny, and D. J. Loskutoff. 1986. Messenger RNA for plasminogen activator inhibitor. Thromb. Res. 41:151-160.

42. Caput, D., B. Beutler, K. Hartog, R. Thayer, S. Brown-Shimer, and A. Cerami. 1986. Identification of a common nucleotide sequence in the $3^{\prime}$-untranslated region of mRNA molecules specifying inflammatory mediators. Proc. Natl. Acad. Sci. USA. 83:1670-1674.

43. Shaw, G., and R. Kamen. 1986. A conserved AU sequence from the 3 ' untranslated region of GM-CSF mRNA mediates selective mRNA degradation. Cell. 46:659-667.

44. Fareed, J., J. M. Walenga, D. A. Hoppensteadt, and H. L. Messmore. 1985. Studies on the profibrinolytic actions of heparin and its fractions. Semin. Thromb. Hemostasis. 11:199-207.

45. Vairel, E. G., H. Bouty-Boye, F. Toulemonde, C. Doutremepuich, N. A. Marsh, and P. J. Gaffney. 1983. Heparin and a low molecular weight fraction enhances thrombolysis and by this pathway exercises a protective effect against thrombosis. Thromb. Res. 30:219224.

46. Paques, E. P., H. A. Stohr, and N. Heimburger. 1986. Study on the mechanism of action of heparin and related substances on the fibrinolytic system: relationship between plasminogen activators and heparin. Thromb. Res. 42:797-807. 